\title{
Nutrition Quality and Microbial Content of Buffalo, Cow, and Goat Milk from West Sumatera
}

\author{
Melia S, Yuherman, Ferawati, Jaswandi, Purwanto H, Purwati E \\ Faculty of Animal Science, Andalas University, Padang \\ E-mail: ferawati@ansci.unand.ac.id
}

(received 10-02-2018; revised 25-06-2018; accepted 01-08-2018)

\begin{abstract}
ABSTRAK
Melia S, Yuherman, Ferawati, Jaswandi, Purwanto H, Purwati E. 2018. Kualitas nutrisi dan kandungan mikrobiologi pada susu kerbau, sapi dan kambing dari Sumatera Barat. JITV 23(3): 150-157. DOI: http://dx.doi.org/10.14334/jitv.v23i3.1594

Penelitian ini bertujuan untuk mengetahui kualitas susu segar secara fisik, kimia dan mikrobiologis yang diperoleh dari ternak sapi, kambing dan kerbau di Sumatera Barat. Parameter yang diukur untuk menentukan kualitas susu segar adalah kandungan nilai gizi, total koloni bakteri aerob dan bakteri asam laktat serta jenis bakteri asam laktat. Hasil penelitian menunjukkan kandungan nilai gizi susu telah memenuhi Standardisasi Nasional Indonesia, tetapi total koloni bakteri aerob berada diatas ambang batas yang diizinkan yaitu $>1 \times 10^{6} \mathrm{CFU} / \mathrm{ml}$. Di samping itu, setiap sampel memiliki total koloni bakteri asam laktat yang bervariasi. Nilai total bakteri asam laktat (BAL) terendah diperoleh pada susu sapi yaitu 0,84 $\pm 0,18 \times 10^{7}$ $\mathrm{CFU} / \mathrm{ml}$, berbeda halnya dengan susu kerbau dan susu kambing yang memiliki total BAL yang lebih tinggi yaitu 36,8 $\pm 17,57$ x10 $\mathrm{CFU} / \mathrm{ml}$ dan 57,25 $\pm 8,89 \times 10^{7} \mathrm{CFU} / \mathrm{ml}$. Namun semua koloni memperlihatkan morfologi isolat BAL yang hampir sama. Dari hasil penelitian disimpulkan bahwa susu segar dari Sumatera Barat mengandung BAL meskipun masih diperlukan pengawasan sanitasi selama penanganan susu.
\end{abstract}

Kata Kunci: Susu Segar, Nutrisi, Total Plate Count, Bakteri Asam Laktat

\section{ABSTRACT}

Melia S, Yuherman, Ferawati, Jaswandi, Purwanto H, Purwati E. 2018 Nutrition quality and microbial content of buffalo, cow, and goat milk from West Sumatera. JITV 23(3): 150-157. DOI: http://dx.doi.org/10.14334/jitv.v23i3.1594

The aim of this research was to determine the quality of fresh milk physically, chemically and microbiologically obtained from cow, goats and buffalo in West Sumatra. The research method applied was laboratory experimental to analyze nutritional value, the number of aerobic bacteria and lactic acid bacteria, isolating and identifying lactic acid bacteria. Results showed that the nutritional value of milk had meet the requirements of Indonesian National Standardization, but the total colony of aerobic bacteria was above the allowed threshold of $1 \times 10^{6} \mathrm{CFU} / \mathrm{ml}$. In addition, each sample had a total colony of varied lactic acid bacteria (LAB). The lowest total LAB value obtained in cow's milk was $0.84 \pm 0.18 \times 10^{7} \mathrm{CFU} / \mathrm{ml}$, in contrast to buffalo milk and goat milk which had a higher total LAB of $36.8 \pm 17.57 \times 10^{7} \mathrm{CFU} / \mathrm{ml}$ and $57.25 \pm 8.89 \times 10^{7} \mathrm{CFU} / \mathrm{ml}$. However, all the colonies showed almost identical morphology of LAB isolates. It is concluded that fresh milk from West Sumatra contains LAB therefore sanitation control is still needed during handling of milk.

Key Words: Fresh Milk, Nutrients, Total Plate Count, Lactic Acid Bacteria

\section{INTRODUCTION}

West Sumatra is a potential area for the development of livestock business. Various livestock business have developed rapidly from year to year. It shows significant increase in production of livestock main products such as egg, meat and milk. Milk production not only comes from cow but also from goat and buffalo. Padang Panjang city is the largest milk supplier in West Sumatera with the highest production of around 405 ton/year (Animal Husbandry and Animal Health Service of West Sumatera Province 2014).

Fresh milk is a liquid derived from healthy and clean cows, obtained by proper milking, which its natural content is not reduced or added by anything and has not received any treatment except cooling (BSN 2011). Milk contains chemical elements needed by the body such as protein and high fat. The main constituents of milk are water (87.9\%), protein (3.5\%), fat (3.5-4.2\%), vitamins and minerals (0.85\%). The $\mathrm{pH}$ value of milk between 6.5 to 6.6 is a very favorable condition for microorganisms, where the $\mathrm{pH}$ around 6.5-7.5 is best for bacterial growth causing milk to easily damage (Estiasih \& Ahmadi 2009). The complete nutritional content of milk becomes a food sources for microbes that cause easly damage of milk. The main damage to milk is caused by the activity of microorganisms that can be a source of 
disease for human who consume it. Proper milk handling is crucial to reduce the contamination and safe for consumption.

High milk production should be supported by good milk quality. Good quality milk is characterized by physical, chemical and microbiological quality. This is a crucial concern because milk is high nutritional food preferred by microorganisms to grow that leads to easily deteriorated milk. The contaminated milk will harmful to the consumer such as causing diarrhea. This disease is caused by the contamination of diseasecausing microbes such as Coliform (Escherechia coli) and Staphylococcus aureus in an amount exceeding the limit of $>2 \times 10^{1}$ (Indonesian National Standard 2000). Usually, these two types of bacteria come from the surrounding environment. This kind of disease is usually called food borne disease. Donkor et al. (2007) described that Coliform bacteria can develop rapidly in humid milk residues in the container, which then becomes the main source of milk contamination. Furthermore, Tamime (2007) explained that pathogenic organisms in milk is bovine mastitis and externally contaminating milk. Bacteria that cause mastitis, which varies geographically and with different livestock practices including $S$. aureus, Streptococcus agalactiae, Str. dysgalactiae, Str. uberis, Listeria spp. and E. coli., $S$. aureus, producing heat-resistant enterotoxins that can cause food poisoning. The Str. agalactiae causes bacteremia and meningitis, which are potentially fatal for infected infants. The Salmonella bacteria and Campylobacter thermoduric strains are the most common pathogens that originate from the external of the udder.

High quality of milk can be seen from the value of its nutritional components such as of water, protein, fat, lactose and total solid. Besides, it also can be from the amount of aerobic and anaerobic bacteria contained in milk, seen as microbiological aspect. The purpose of this activity was to study the quality of nutrients and microbiology of buffalo, cow and goat milk from West Sumatra.

\section{MATERIALS AND METHODS}

The materials used in this study were: fresh milk (from cows, goats and buffaloes) obtained from five locations, Payakumbuh, Sijunjung, Tanah Datar, Padang Panjang and Solok in West Sumatra; Man Rogossa sharpe Agar (MRSA) (Merck ); MRSB (Merck); Nutrient Agar (NA) (Merck); PCA (Plate Count Agar), pepton water; destlilled water; alcohol; and spritus. The equipments used were laminar flow (AlabTech), cool box (Coleman), thermometer, $\mathrm{pH}$ meter (HANNA instrument $\mathrm{pH}$ meter), petri dish, ose needle, incubator (INFORS AG-CH-4103 BOTTMIGEN), measuring cup, analytical scales KERN ABT 320-4M), erlenmeyer, bunsen lamp, test tube, beaker glass, dropper drip, hockey stick, autoclave, centrifuge (5417 R), vortex, spectrophotometer (Shimadzu UV-1800 series), oven (Memmert) and micro pipette (Thermo). The research was conducted in Animal Production Technology Laboratory and Biotechnology Laboratory-Faculty of Animal Husbandry, the University of Andalas during January - June 2017.

Those cow, goat and buffalo milk collected from farms were stored in cool boxes until samples were analyzed in the laboratory. A total 15 samples collected randomly at three sites in each location, with 3 repetitions. Milk was milked from 4-6 years old goat, of $3.5-5$ years old cow and 3-4 years old buffalo. The milk collection was done during milking in the morning at 06.00 - 08.00 WIB.

Proximate Analysis. Proximate analyzes performed were test of water content, protein, fat, lactose, total solid, and pH (AOAC 2012)

Total colonies of aerobic and lactic acid bacteria. To calculate total colony of aerobic lactic acid bacteria was done according to Purwati et al. (2005). Calculation of the number of colonies of aerobic bacteria contained in the sample was done by the following procedure: All equipment needed was sterilized first with autoclave at $121^{\circ} \mathrm{C}$ for 15 minutes with $15 \mathrm{lb}$ pressure. The medium used was 23.5 gram Plate Count Agar (PCA) that dissolved with $1000 \mathrm{ml}$ of aquades, 20 grams of pepton water dissolved with $1000 \mathrm{ml}$ of aquades, then homogenized with magnetic stirrer above hot plate at $100^{\circ} \mathrm{C}$ and sterilized in autoclave. A total of $1 \mathrm{ml}$ sample that was dissolved in $9 \mathrm{ml}$ pepton, then was vortexed for 5 minutes until the average yield called 101 dilution. The dilution was then taken $100 \mu \mathrm{l}$ which already contained $900 \mu \mathrm{l}$ pepton water solutions. The result was called 10-2 dilution. And so on until 10-7 dilution. Furthermore, the total of $100 \mu \mathrm{l}$ of the 10-7 was taken to be spread on petridish that has contained frozen PCA. The petridish was stored in an incubator for 24 hours at $37^{\circ} \mathrm{C}$ which has already been coded. After 24 hours, bacterial colonies grown were calculated using the Quebec Colony Counter (Colony Forming Unit) tool. The number of colonies was multiplied by 10 that formed in the calculation formula bellow:

$$
\text { CFU/gram }=\text { The number of colony } \quad x \frac{1}{\text { Dilution }} \quad x \quad \frac{1}{\text { The weight of sample }}
$$


The calculation of total LAB of Purwati et al. (2005) was prepared by sterilizing all the equipment in the autoclave at $121^{\circ} \mathrm{C}$ for 15 minutes at a pressure of 15 lbs. Media prepared was De Mann Ragosa Sharpe (MRS) Broth (Merck). A total of $1 \mathrm{ml}$ of milk was dissolved in a reaction tube containing of $9 \mathrm{ml}$ of de mann Ragosa Sharpe (MRS) Broth solution, then vortexed until homogeneous. The result was called 10-1 dilution, then it was incubated for 24 hours in an incubator at $37^{\circ} \mathrm{C}$. A total of $100 \mu \mathrm{l}$ of the dilution was inserted into an eppendrof tube containing of $900 \mu \mathrm{lde}$ mann Rogosa Sharpe (MRS) Broth solution, then vortexed until homogeneous. The result of this dilution was called dilution $10-2$, and so on until it formed dilution $10-8$. It is taken $100 \mu$ of dilution $10-8$ and spread on petridish which already contain MRS media so that then flattened with hokey stick which have been sterilized by alcohol and burned with Bunsen then aerated. The inoculum was stored in an anaerobic jar and incubated in an incubator for 48 hours at $37^{\circ} \mathrm{C}$. The petridish was marked as code. After 48 hours, the single colony that had characterizes of the LAB such as yellowish smooth round was calculated and inserted into the same formula as the TPC formula above.

\section{Isolation and identification of lactic acid bacteria}

Morphology of lactic acid bacteria is known macroscopically and microscopically and followed by biochemical test (gram staining and catalase test) in accordance to Purwati et al. (2005).

a. Macroscopic: Visual observation done on shape, size, color, and elevation

b. Microscopic: Shape of cell using microscope 400x and $1000 \mathrm{x}$

c. Biochemistry (Color Staining and Cathalase Test)

\section{Data analysis}

Data processing was done by determining the average obtained from 3 repetitions on proximate and microbiological analysis then it was counted the standard deviation.

\section{RESULTS AND DISCUSSION}

\section{Proximate analysis of milk}

The proximate test is part of the method to determine the quality of milk. The tests included determination of water content, protein content, fat content, lactose and total solid. Results of proximate analysis of buffalo, cow and goat milk is presented in Table 1.

The analysis result showed that the average water content in buffalo milk was $78.91 \%$. This is lower than the research of Han et al. (2012) that showed buffalo milk content was around $83 \%$. The average water content of cow milk in West Sumatra (80.82\%) was lower compared to Taufik (2004) that was $87.89 \%$. This can be caused by the high fat content of cow's milk leads high total solid milk. Another factor that also affects the milk content is the type and amount of feed given. This is in accordance with Lingathurai et al. (2009) who stated that the physical and chemical quality of fresh cow's milk is influenced by dairy breed, feed, feeding, milking frequency, milking method, seasonal and the location when lactation.

Protein content of buffalo, goat and cow milk obtained from various breeders in West Sumatra is presented in Table 1. Buffalo milk protein is $6.77 \%$ that higher than the buffalo milk protein content in the study of Wirdahayati (2006) of 5.62\%. The protein content of cow milk in this study (3.71\%) is also higher compared to cow milk protein content in Suhendar et al. (2008) of $3.2 \%$. While the Indonesian National Standard (INS) Number 01-3141-2011, the minimum protein content in fresh cow's milk is $2.8 \%$. It means that the cow milk has met the INS. Furthermore, protein content of goat milk in this study is $4.39 \%$ higher compared to research Watson et al. (2017) of 3-4\%.

Table 1. Average of proximate analysis of buffalo, cow, and goat milk in West Sumatera

\begin{tabular}{lccccccc}
\hline \hline Milk & $\begin{array}{c}\text { The number } \\
\text { of sample }\end{array}$ & $\begin{array}{c}\text { Water level } \\
(\%)\end{array}$ & $\begin{array}{c}\text { Protein level } \\
(\%)\end{array}$ & Fat level (\%) & Lactose (\%) & $\begin{array}{c}\text { Total solid } \\
(\%)\end{array}$ & $\mathrm{pH}$ \\
\hline $\begin{array}{l}\text { Buffalo } \\
\text { milk }\end{array}$ & 45 & $78.91 \pm 0.75$ & $6.77 \pm 0.31$ & $7.25 \pm 0.16$ & $5.28 \pm 0.12$ & $19.31 \pm 0.28$ & $6.60 \pm 0.14$ \\
Cow milk & 45 & $80.82 \pm 0.05$ & $3.71 \pm 0.32$ & $5.21 \pm 0.23$ & $4.34 \pm 0.26$ & $13.26 \pm 0.35$ & $6.40 \pm 0.06$ \\
Goat milk & 45 & $82.21 \pm 0.89$ & $4.39 \pm 0.22$ & $6.41 \pm 0.36$ & $4.58 \pm 0.07$ & $15.64 \pm 0.48$ & $6.40 \pm 0.16$ \\
INS & & & Min 2.8\% & $\geq 3 \%$ & $\begin{array}{c}3.00-5.80 \\
\mathrm{mg} / 100 \mathrm{ml}\end{array}$ & $12-13 \%$ & $6-7$ \\
\hline
\end{tabular}


High level of protein in goat's milk is expected to be influenced by the animal feed itself. Generally, the management pattern of goats in West Sumatra has begun to pay attention to the adequacy of nutritional value. It is not only sourced from grass as forage but also the adequacy of concentrate for goats. This is in line with the Melia \& Sugitha (2007) who stated that the concentrate is a feed ingredient that has a complete nutritional content, so it will affect the amount of solid of non-fat content in milk including protein.

The fat content of milk in this study was in the higher range than the minimum limit in the Indonesian National Standard/Badan Standarisasi Nasional (INS/BSN) Number 01 01-3141-2011 about - Terms of Quality Fresh milk that is at least 3\%. In this research, the fat content of buffalo, cow, and goat milk was $7.25 \%, 5.21 \%$, and $6.41 \%$, respectively. Factors affecting milk fat levels are animal breed maintained, milking age, lactation levels, milking intervals, local climatic conditions and diet given. If the dominant diet given is forage, the fat content in milk will be high due to the crude fiber consumed will be fermented by rumen microbes to produce acetic acid as the basic ingredient of milk fat formation (Tyler \& Ensminger 2006). The lactose content of buffalo, cow and goat milk in this study was $5.28 \%, 4.34 \%$, and $4.58 \%$ respectively. Normal milk lactose content is about 4\% (Sinuhaji 2006). The lactose content of cow, goat and buffalo milk in this study was already in the range of normal values.

The composers of total solids in milk are proteins, fats, lactose, vitamins, and minerals. According to Haenlein (2002), the total solid milk content is $12-13 \%$. The total solid content of goat's milk in this study was $15.64 \%$ higher than the normal total solid. The total solid value of milk is influenced by the fat content of milk, solid nonfat and specific gravity of milk. The total solid content is highly dependent on fat content and solid nonfat. If you see total solid content of buffalo milk was higher than cow's milk (19.31\%) while cow milk was $13.26 \%$. Buffalo milk has average solid total of 16-18\% (Han et al. 2012). The total solid of buffalo milk of this study is similar to Kapadiya et al. (2016) showed that total solid milk buffalo is higher than the total solid of cow and goat milk.

The $\mathrm{pH}$ of milk on the Indonesian National Standard (INS) Number 01-3141-1998 about Quality Requirement Fresh Milk is ranged around 6-7. When the $\mathrm{pH}$ of milk is higher than the normal limit it can usually be interpreted that the animal is exposed to mastitis. While, when it is below than 6.5 , it can be caused by bacteria or is a sign of milk colostrum (Watson et al. 2017). The $\mathrm{pH}$ of milk in this study (Table 1) shows that milk in West Sumatra is in normal category. Most of the acids present in milk are lactic acid. Based on the nutrient content and $\mathrm{pH}$ value, those milk sample collected in West Sumatra already meets the standards according to INS (Indonesian National Standard).

Goat milk contains higher unsaturated fatty acids and more medium chain triglycerides than cow and buffalo milk that good for health, especially for the heart by lowering blood cholesterol levels (Haenlein 2004). The content of cholestrerol in goat milk of 12 $\mathrm{mg} / 100 \mathrm{ml}$ was lower than cow milk of $17 \mathrm{mg} / 100 \mathrm{ml}$. Besides, fatty acids in goat milk such as caprylate is able to remove dead skin cells, it is why goat milk is widely used for the manufacture of high economic value-cosmetic materials (Alo 2008).

\section{Total colony of aerob and lactic acid bacteria of milk}

The microbiological characteristic as a parameter of milk quality is based on the amount of aerobic bacteria contamination. However, the amount of lactic acid bacteria indicates the potential of milk as probiotics. The analysis result of the total colonies of aerobic and lactic acid bacteria in fresh milk in West Sumatra is presented in Table 2.

The results of TPC calculation of buffalo, cow, and goat milk can be seen in Table 2 . It shows that milk in West Sumatera exceeds the limit of TPC threshold set by the INS. Indonesian National Standard (INS) Number 01-3141-1998 is on the Quality Requirement of Fresh Milk and INS Number 7388: 2009 is on the Maximum Limit of Microbe Contamination in Food.

Table 2. Average total colony of aerob and lactic acid bacteria of buffalo, cow and goat milk in West Sumatera

\begin{tabular}{lccc}
\hline \hline Sample & The number of sample & Total LAB $\left(\times 10^{7}\right)$ & TPC $\left(\times 10^{5}\right)$ \\
\hline Buffalo milk & 45 & $36.8 \pm 17.57$ & $296 \pm 16.63$ \\
Cow milk & 45 & $0.84 \pm 0.18$ & $33 \pm 11.61$ \\
Goat milk & 45 & $57.25 \pm 8.89$ & $116.5 \pm 7.73$ \\
INS & - & & $\leq 1 \times 10^{6} \mathrm{CFU} / \mathrm{ml}$
\end{tabular}


The INS suggests that bacterial or microbial contamination is $1 \times 10^{6} \mathrm{CFU} / \mathrm{ml}$ of Total Plate Count/TPC. The results of this study did not differ much from the results of Zeinab et al. (2008) that showed an average TPC values in cow's milk in Sudan state of $7.98 \mathrm{log} / \mathrm{ml}$. This illustrates the lack of sanitation in the management of animal management and post-milk handling.

High TPC value obtained in West Sumatera is allegedly caused by the manual milking and handling process carried by the farmers. A semi-permanent cattle enclosure, the sewer that close to the milking site and no special milking place cause easy milk to be contaminated by the fecal bacteria. Dairy milking equipment is one of the causes of high TPC in milk in West Sumatra. During the research it was informed that milking was usually done in open cages that allow for contamination through the air, equipment or cattle body (Donkor et al. 2007). Poor hygiene in this study indicated the presence of milk contamination from the milking environment.

High TPC values in cow, goat and buffalo milk show a contamination in milk both from outside and other sources. Contamination in milk by pathogenic or non-pathogenic bacteria may come from the cow itself, milking equipment, not clean storage room, dust, air, flies, and wrong handling by humans (Roumbaut 2005). According to Cempirkova (2006), a total of $64 \%$ of microorganisms in milk come from poor hygiene, $28 \%$ by low temperatures (psychotrophic bacteria) and poor storage, and $8 \%$ by mastitis. It is supported by Lues et al. (2010) who stated that cows with mastitis may lead the number of TPC to reach $1 \times 10^{7} \mathrm{CFU} / \mathrm{mL}$. There are two types of mastitis in dairy cattle: clinical and subclinical mastitis. Clinical mastitis is characterized by the changes in milk that looks clot or liquid and mixed with blood or pus. While sub-clinical mastitis cannot be observed directly so it is necessary to test using a special mastitis reagent (Sudono et al. 2003). However, direct observation of animal conditions in this study did not indicate the symptoms of clinical mastitis. According to Ortolani et al. (2010), the presence of aerobic microbes is often regarded as an important microbiological factor for the quality parameters of milk and dairy products at an amount of higher than $10^{5}$ $\mathrm{CFU} / \mathrm{mL}$ so as to indicate the cleanliness of production, while the values that lower than 20,000 CFU/mL shows good sanitation practices.

Table 2 shows that in fresh cow, goats and buffalo milk there are also lactic acid bacteria. Rizqiati et al. (2015) said that milk from various types of mammals can be used as a source of Lactic Acid Bacteria (LAB) and buffalo milk is the source of various potentially probiotic LABs. Kumar \& Murugalatha (2012) found a species of lactic acid bacteria, Lactobacillus plantarum isolated from cow's milk that has the ability to kill various types of pathogenic bacteria. Lactic acid bacteria are widely spread in nature. It naturally occur due to the original microflora in raw milk is a very active gram-positive bacteria in food processing and feed fermentation (Guessas \& Kihal 2004). Then, Ortolani et al. (2010) stated that the LAB can be used as biopreservative in food. Lactic acid bacteria are grampositive, non-spore, spherical or stem bacteria that produce lactic acid as the final product of carbohydrate fermentation.

Lactic acid bacteria (LAB) can be isolated from various natural sources, such as from soil; plants; water; sewage and also from the genital tract and human and animal digestion (Sujaya et al. 2016). The current utilization of LAB is not only to produce food as it has been widely used as fermented starter for the manufacture of cheese, yoghurt and curd but the LAB is used as a probiotic that has many functions, especially plays an important role in the digestive tract. In line with Noordiana et al. (2013) who said that lactic acid bacteria are also classified as probiotic bacteria which have antimicrobial activity against certain microorganisms. While Kim et al. (2006) stated that BAL is also tolerant of stomach acid and harmless.

\section{Isolation and identification of lactic acid bacteria}

Identification of lactic acid bacteria isolates using morphological features, as well as gaseous formation of glucose can only group the LAB as Lactobacillus spp. (for isolates with rod shape), Pediococcus spp. (for isolates with round/coccus), Lactococcus/Enterococcus spp. (for isolates with cocco bacil form) (Sujaya et al. 2016). Morphology characteristic of isolates of LAB is known by gram staining.

The identification of LAB in fresh milk obtained from West Sumatera region was done through several conventional test stages, namely the determination of isolate morphology, gram staining test and catalase test grouped as Gram-positive bacteria. Melia et al. (2017) stateed that LAB isolated from buffalo milk has potential as probiotics and inhibits the growth of pathogenic bacteria, including Lactobacillus fermentum. The result of identification of lactic acid bacteria conventionally in this study is presented in Table 3.

The principle of $\mathrm{LAB}$ isolation is to obtain a single colony to determine the properties of LAB. LAB identification is indicated by gram staining and catalase test and morphological characteristics of each isolate (shape, size, elevation, color). Gram staining test result showed purple-colored and tube-shaped. This shows that the isolates tested are gram positive. While the catalase test on all isolates did not show any gas bubbles after spilled with hydrogen peroxide $\left(\mathrm{H}_{2} \mathrm{O}_{2}\right)$. 
Table 3. Morphology of lactic acid bacteria of fresh milk in West Sumatera

\begin{tabular}{|c|c|c|c|c|c|c|c|}
\hline Sample & Isolate & Shape & Size & Color & Elevation & $\begin{array}{c}\text { Gram } \\
\text { staining }\end{array}$ & Catalase test \\
\hline \multirow[t]{4}{*}{ Buffalo milk } & BM 1.1. & Tube & $3 \mathrm{~mm}$ & Beige & Convex & Positive & Negative \\
\hline & BM 2.1 & Tube & $3 \mathrm{~mm}$ & Beige & Convex & Positive & Negative \\
\hline & BM 3.2 & Tube & $3 \mathrm{~mm}$ & Beige & Convex & Positive & Negative \\
\hline & BM 4.2 & Tube & $2 \mathrm{~mm}$ & Beige & Convex & Positive & Negative \\
\hline \multirow[t]{4}{*}{ Cow milk } & CM 1.1 & Tube & $2 \mathrm{~mm}$ & Beige & Convex & Positive & Negative \\
\hline & CM 1.2 & Tube & $3 \mathrm{~mm}$ & Beige & Convex & Positive & Negative \\
\hline & CM 2.1. & Tube & $2 \mathrm{~mm}$ & Beige & Convex & Positive & Negative \\
\hline & CM 2.2 & Tube & $3 \mathrm{~mm}$ & Beige & Convex & Positive & Negative \\
\hline \multirow[t]{4}{*}{ Goat milk } & GM 1.1 & Tube & $2 \mathrm{~mm}$ & Beige & Convex & Positive & Negative \\
\hline & GM 2.1 & Tube & $1 \mathrm{~mm}$ & Beige & Convex & Positive & Negative \\
\hline & GM 3.1 & Tube & $3 \mathrm{~mm}$ & Beige & Convex & Positive & Negative \\
\hline & GM 4.2 & Tube & $2 \mathrm{~mm}$ & Beige & Convex & Positive & Negative \\
\hline
\end{tabular}

These results indicate that the isolates are catalase negative. Based on the API 50 CHL test, it is known that generally lactic acid bacteria contained in all milk samples is Lactobacillus fermentum. Then Axelsson (2004) said that lactic acid bacteria are tube and round gram-positive bacteria and are negative catalase. Rizqiati et al. (2015) found lactic acid bacteria derived from buffalo milk present in North Sumatra, namely Lactobacillus plantarum, L. brevis, L. paracasei, L. pentosus and Lactococcus lactis. Surono (2016) stated that lactic acid bacteria is a bacterium that acts as a probiotic derived from milk and fermented milk product, which is beneficial for digestive tract health.

\section{CONCLUSION}

It can be concluded that the nutritional content of fresh milk obtained from cow, buffalo and goat in West Sumatra were already meet the requirements of fresh milk quality according to BSN No. 3141.1: 2011. Meanwhile, microbiologically all fresh milk samples had aerobic microbial contamination over the threshold allowed of $1 \times 10^{6} \mathrm{CFU} / \mathrm{ml}$. A high number of LABs indicated that milk in this study could potentially be a source of probiotics.

\section{ACKNOWLEDGEMENT}

We thank the Head of Directorate of Research and Community Services, Ministry of Technology Research and Higher Education with Contract Number of 059/SP2H/LT/DRPM/IV/2017 who funded this research. Also to Rector of University of Andalas, Head of Research Institute and Community Services, Deans, Head of Animal Product Processing Technology Department, Head of Animal Product Laboratory, and Head of Animal Biotechnology laboratory.

\section{REFERENCES}

[AOAC] Association of Official Analytical Chemists. 2012. Official methods of analysis. 19th ed. Washington DC (USA): Association of Official Analytical Chemists.

Alo AMP. 2008. Trends in goat production in the Philippines. Proceeding of International Seminar on Meat and Dairy Goat Production. Bogor (Indones): IRIAP \& FFTC.

Animal Husbandry and Animal Health Service of West Sumatera Province. 2014. Sumatera Barat dalam Angka Tahun 2014. Padang (West Sumatra): Dinas Peternakan dan Kesehatan Hewan, Propinsi Sumatera Barat. 
Axelsson L. 2004. Lactic acid bacteria: Classification and physiology. New York (USA): Marcel Dekker Inc. p. 1-73.

[BSN] Badan Standarisasi Nasional. 2009. Standar Nasional Indonesia (SNI) No. 7388-2009 tentang batas maksimum cemaran mikroba dalam pangan. Jakarta (Indones): Badan Standarisasi Nasional.

[BSN] Badan Standarisasi Nasional. 2011. Standar Nasional Indonesia (SNI) No. 01-3141-2011 tentang susu segarbagian 1 sapi. Jakarta (Indones): Badan Standarisasi Nasional.

Cempirkova R. 2006. Factors negatively influencing microbial contamination of milk. J Agric Trop Et Subtrop. 39:220-221.

Donkor ES, Aning KG, Omore A, Nurah GK, Osafo ELK, Stall S. 2007. Risk Factor in hygienic quality of milk in Ghana. Open Food Sci J. 1:6-9.

Estiasih T, Ahmadi. 2009. Teknologi pengolahan pangan. Jakarta (Indones): Bumi Aksara.

Guessas B, Kihal M. 2004. Cahracterization of lactica acid bacteria isolated from Algerian arid zone raw goat's milk. AJ Biotechnol. 3:339-342.

Haenlein GFW. 2002. Feeding goats for improved milk and meat production. [accessed August 5th 2017]. http://ag.udel.edu/extension/information/goatmgt/gm$02 \mathrm{htm}$.

Haenlein GFW. 2004. Goat milk in human nutrition. Small Rumin Res. 51:155-163.

Han X, Lee FL, Zhang, Guo LMR. 2012. Chemical composition of water buffalo milk and its low-fat symbiotic yogurt development. Funct Foods Health Dis. 2:86-106.

Kapadiya DB, Prajapati DB, Jain AK, Mehta BM, Darji VB, Aparnathi KD. 2016. Comparison of Surti goat milk with cow and buffalo milk for gross composition, nitrogen distribution, and selected minerals content. Vet World. 9:710-716.

Kim HJ, Shin HS, Ha WK, Yang HJ, Lee SW. 2006. Characterization of Lactic Bacterial Strains Isolated from Raw Milk. Asian-Aust J Anim Sci. 19:131-136.

Kumar AM, Murugalatha N. 2012. Isolation of Lactobacillus plantarum from cow milk and screening for the presence of sugar alcohol producing gene. J Microbiol Antimicrob. 4:16-22.

Lingathurai S, Vellathurai P, Vendan SE, Anand AAP. 2009. A comparative study on the microbiological and chemical composition of cow milk from different locations in Madurai, Tamil Nadu. Indian J Sci Technol. 2:51-54.
Lues JFR, De Beer H, Jacoby A, Jansen KE, Shale K. 2010. Microbial quality of milk, produced by small scale farmers in a Peri-urban area in South Africa. Afr J Microb Res. 4:1823-1830.

Melia S, Sugitha IM. 2007. Kualitas dadih susu sapi mutan Lactococcus lactis pada level waktu fermentasi. J Indones Trop Anim Agric. 32:86-90.

Melia S, Purwati E, Yuherman, Jaswandi, Aritonang SN, Silaen HM. 2017. Characterization of the antimicrobial activity of lactic acid bacteria isolated from buffalo milk in West Sumatera (Indonesia) against Listeria monocytogenes. Pak J Nutr. 16:645-650.

Noordiana N, Fatimah AB, Mun AS. 2013. Antibacterial agent produces by Lactic Acid Bacteria isolated from Threadvin salmon and Grass shrimp. Int Food Res J. 20:117-124.

Ortolani MBT, Yamazi AK, Moraes PM, Vicosa GN, Nero LA. 2010. Microbiological quality and safety of raw milk and soft cheese and detection of Autochthonous Lactic Acid Bacteria with antagonistic activity against Listeria monocytogenes, Salmonella Spp., and Staphylococcus aureus. Foodborne Path Dis. 7:175-180.

Purwati E, Syukur S, Hidayat Z, 2005. Lactobacillus sp. isolasi dari Biovicophitomega sebagai probiotik. Jakarta (Indones): Lembaga Ilmu Pengetahuan Indonesia.

Rizqiati H, Sumantri C, Rachman NR, Damayanthi E, Ida RE. 2015. Characteristics of indigenous probiotic from River buffalo milk in North Sumatra Indonesia. Int J Sci: Basic Appl Res. 22:113-120.

Roumbaut R. 2005. Dairy microbiology and starter cultures. Belgium: Laboratory of Food Technology and Engineering, Gent University.

Sinuhaji AB. 2006. Intoleransi laktosa. Majalah Kedokteran Nusantara. 39:424-429.

Suhendar Y, Dadang WI, Mardi T, Riyanto S, Palupi IR, Sucahyo O. 2008. Pascapanen lalai kualitas susu terbengkalai. [accessed April 23th 2017]. http://www.agrina-online.com/show_article.php?rid=7\& aid $=1257$.

Sujaya NI, Komang AN, Aryantini DPN, Wayan N, Yan R, Yoshitake O, Fukuda K, Tadashu U, Yuji O. 2016. Identification and characterization of Lactic Acid Bacteria isolated from Bali cattle's raw milk. J Veteriner. 17:155-167.

Sudono A, Rosdiana FR, Setiawan BS. 2003. Beternak sapi perah secara intensif. Jakarta (Indones): Agromedia Pustaka.

Surono IS. 2016. Probiotik, mikrobiome dan pangan fungsional. Yogyakarta (Indones): Deepublish. 
Tamime AY. 2007. Milk processing and quality management. New Jersey (USA): Blackwell Publishing Ltd.

Taufik E. 2004. Dadih susu sapi hasil fermentasi berbagai starter bakteri probiotik yang disimpan pada suhu rendah: Karakteristik kimiawi. Media Peternakan. 27:88-100.

Tyler HD, Ensminger ME. 2006. Dairy cattle science. 4th ed. Ohio (USA): Pearson Prentice Hall.
Watson RR, Collier RJ, Preedy VR. 2017. Nutriens in dairy and their implication for health and disease. Cambridge, Massachusetts (USA): Academic Press.

Wirdahayati RB. 2006. Produktivitas ternak kerbau penghasil dadih di Sumatera Barat. J Ilmiah Tambua. 1.

Zeinab AM, Elgadi, Warda S, Gadir A, Dirar HA. 2008. Isolation and identification of Lactic Acid Bacteria and yeast from raw milk in Khartoum State (Sudan). Res J Microbiol. 3:163-168. 